\title{
Bilgi ve Belge Hizmetlerinde Mükemmeli Yakalamak: Örnekedinme
}

\author{
Benchmarking Practices in the Information and \\ Documentation Centers
}

\section{Mesut KURULGAN}

\begin{abstract}
Öz
1980'lerden önce bilgi-belge merkezleri (BBM) hizmetlerinin kalitesini ölçmede kullanıcı memnuniyetini esas alıyorlardı. 1980'den sonraki dönemde; BBM'ler eğitim ve bilgi hizmetlerinin etkinliğini artıran temel unsurlardan biri olan toplam kalite yönetimini fark ettiler ve uygulamaya başladılar. BBM'ler, 20 yıldan daha fazla bir süredir, kullanıcılara sunulan hizmeti geliştirmek için yeni araç ve süreçlerden yararlanma yoluna gitmektedirler. Bu süreçlerden bir tanesi de 'örnekedinme'dir. Literatüre bakıldığı zaman, BBM'lerde örnekedinmenin rekabetçi, işbirlikçi, içsel, nicel ve nitel örnekedinme gibi birçok türünün kullanıldı̆̆ı görülmektedir. Bu çalışmada örnekedinme süreci kısaca tanımlanarak; Türkiye ve dünyadaki bilgi-belge merkezlerindeki örnekedinme uygulamalarına yer verilmektedir.
\end{abstract}

Anahtar sözcükler: Bilgi-belge merkezleri, Örnek edinme, Toplam kalite yönetimi.

\begin{abstract}
Prior to 1980's most of the Information and Documentation Centers (IDC) had adopted customer satisfaction as the quality criterion of their services. During the 80's IDC's became aware of Total Quality Management as one of the primary influencing factors in increasing the efficiency of information services and began its implementation. For over 20 years they have been using instruments and processes to improve services offered to users. One of these is benchmarking. Different benchmarking processes such as those of competitive, cooperative, internal, quantitative and qualitative types were all utilized by IDC's. This study briefly explains the benchmarking process and
\end{abstract}

“Yrd. Doç. Dr.; Anadolu Üniversitesi Porsuk Meslek Yüksekokulu Basın Şehitleri Caddesi 26140 Eskişehir(mkurulgan@gmail.com). 
examines various practices of benchmarking in Information and Documentation Centers in the World and in Turkey.

Keywords: Information and documentation centers, Benchmarking, Total quality management.

\section{Giriş}

Mal ve hizmet üretimindeki gelişmeler, müşteri memnuniyetinin ön plana çıktığı rekabet koşullarına özgü tartışmaları, kalite bilincini ve yönetim modellerindeki gelişmeleri gündeme getirmiştir. Bu amaçla 1945’lerde Japonya'da Deming'in katkısıyla "kalite kontrolü" adıyla başlatılan kalite hareketi, 1950'li yıllarda "toplam kalite kontrolü", 1960’larda "kalite güvencesi", 1980'li yıllarda "toplam kalite yönetimi (TKY)" adlarıyla anılan anlayış genişletimine ulaşmıştır. İlk olarak mal üreten işletmelerde görülen TKY felsefesi, daha sonraları bilgi belge merkezleri (BBM)'nde de uygulama alanı bulmaya başlamıştır (Kurulgan, 2004, s. 164).

TKY sürecinin bir parçası olan "örnekedinme (benchmarking)", müşterilere sunulan hizmeti geliştirmek için yararlanılan yönetsel araçlardan biridir. ABD'de uygulanmaya başlayan ve bütün ülkelerde yaygınlaşan "benchmarking" ülkemizde "kıyaslama", "en iyi uygulamaların adaptasyonu", "başkalarından öğrenmek" ya da "nirengileme" olarak dilimize kazandırımaya çalışılmaktadır. Benchmarking kavramı bu çalışmada "örnekedinme/kıyaslama" olarak ifade edilmektedir.

Çalışmada, TKY felsefesinde önemli bir yönetsel araç olarak yararlanılan "örnekedinme" yaklaşımının BBM kullanımını irdelemek amacıyla literatürden elde edilen bilgiler değerlendirilmekte, dünyadan ve Türkiye'den uygulama örneklerine yer verilmektedir.

\section{Örnekedinmenin Tanımı ve Kavramsal Çatısı}

"Benchmark" kavramı topografyadan gelmektedir. Benchmark, haritacıların referans noktası olarak kullandıkları bir nesnenin yüksekliğini gösteren işarete atıf yapmaktır. Örgüt yapısına bunun uygulanışında ise örnekedinme, bir işletmenin, en iyi uygulamalara sahip olmasıyla tanınan diğer kuruluş ya da kuruluşların ürünlerini, hizmetlerini, iş süreçlerini kendilerininki ile karşılaştırarak değerlendireceği sürekli ve sistemli bir süreç olarak düşünülebilir (Bedük, 2002, ss. 5-6). 
Genel olarak belirtmek gerekirse; örnekedinme belli bir örgütsel işlevin ya da uygulamanın örgütler arasındaki karşılaştırımasıdır. Örnekedinme uygulaması, yöneticilerin kendi başarımlarının (performanslarının) diğerlerinden hangi yönlerde farklılaştığını görmelerini sağlar. O halde örnekedinme (Maviş, 1998, s. 220):

$>\quad$ Örgüt başarımını sınıfındaki en iyi olanla karşılaştırarak ölçme,

$>\quad$ En iyi olanın bu başarım düzeyine nasıl ulaştığını belirleme,

$>\quad$ Ulaşılan bilgiyi kendi örgütünün hedefleri, stratejileri ve uygulamaları için temel almasıdır.

\section{Bilgi-Belge Merkezlerinde Örnekedinme Süreci ve Uygulamaları}

Rakipten öğrenme, gerekirse aynen taklit etme veya esinlenme, uygarlık yolunda bir yaşam yaklaşımıdır. Örneğin; Ford'un ünlü bant sistemi bir mezbahadan, Toyota üretim sistemindeki "tam zamanında üretim" ise; bir süpermarketten esinlenerek ortaya çıkmıştır. Ford'un kurucusu Henry Ford, yürüyen bant sistemiyle üretimi, bir tanıdığını görmek için gittiği bir mezbahadan esinlenerek geliştirmiştir. Kasapların her birinin, karkasın (kemikli sığır eti) belirli bir bölümünü keserek kalanını diğer arkadaşlarına devrettiğini gören Ford, aynı yöntemi otomobil yapımında, çengellerin üzerinde kayan çelik ray yerine hareketli bir bant kullanarak gerçekleştirmiştir (Capital, 1998, s. 7).

İlk kez sanayi işletmelerinde başlayan örnekedinme çalışmaları, günümüzde hizmet işletmelerini ve bu bağlamda değerlendirilebilecek BBM'ni de kapsamına almaktadır.

TKY kapsamındaki araç ve tekniklerden birisi de örnekedinme yöntemidir. Bu yöntemde süreçlerin sürekli olarak iyileştirilmesi hedeflendiğinden, TKY'yi ve örnekedinmeyi birbirinden ayrı düşünmek doğru bir yaklaşım tarzı olamaz.

\section{Örnekedinme Türleri}

Kendi alanlarında en iyi olmayı hedefleyen BBM'leri, rakiplerini de her yönüyle izlemek durumundadır. Bugün sektörde en iyi olan bilgi-belge merkezleri, bulundukları konuma, diğer BBM'lerin bilgi ve birikimlerinden yararlanarak gelmişlerdir. Bu duruma ulaşılma sürecinde, BBM'lerin kendi hizmet kalitelerinde ve bununla birlikte kullanıcı memnuniyetinde hızlı atıımlar gerçekleştirilmiştir. BBM'lerin kullanabilecekleri çeşitli örnekedinme türleri şunlardır (Jager, 1999, ss. 368-369): 
$>$ Rekabetçi Örnekedinme: Bir BBM'nin kendi işlevlerini, süreçlerini, faaliyetlerini, ürün/hizmetlerini ölçerek; aynı sektörde hizmet veren ve aynı ölçümlemede daha iyi olan rakip BBM'lerin uygulamalarının incelenme sürecini kapsamaktadır. Ancak bu yöntemde, doğrudan rakip BBM'ler hakkında güvenilir bilgiler elde etmek oldukça güç bir iştir. Bu konuda önemli bir bilgi kaynağı olarak; BBM'leri farklı açılardan tarafsız bir biçimde inceleyen anket sonuçları ve raporlardan yararlanılmaktadır.

$>$ Işbirlikçi Örnekedinme: Bu yöntemde, örneğin; bir üniversite kütüphanesinin, (ulusal kütüphane, halk kütüphanesi, arşiv gibi) doğrudan rakibi durumunda olmayan en iyi BBM'lerle işbirliğine girerek, onların belirli süreçleri hakkında bilgi edinme yoluna gitmesi söz konusudur. Örneğin; bir üniversite kütüphanesinin ödünç verme uygulamaları, çeşitli ülkelerin ulusal kütüphanelerindeki uygulamalar ile karşılaştırılabilir. Ayrıca çeşitli BBM'lerin bir araya gelerek oluşturdukları konsorsiyumların başarıları da bu yönteme bir örnek olabilir.

> IÇsel / Işsletme Içi Örnekedinme: Bu yaklaşım yöntemiyle örneğin; üniversite kütüphanesi ile birbirine benzer faaliyetlere sahip, üniversitenin çeşitli birimlerinde faaliyet gösteren şube kütüphaneleri, dokümantasyon merkezleri vb. birimlerin çeşitli konularda yaptıkları uygulamalar karşılaştırılmaktadır.

> Nicel Örnekedinme: Bir BBM'nin, kendi uygulama ölçüm sonuçlarını diğer en iyi uygulama ölçüm sonuçlarıyla sayısal olarak karşılaştırması yöntemidir. Bilgi sermayesinin örneğin yazılım, patentler, işgören eğitimi ve diğer bilgi kaynaklarının nicel olarak ölçülmesinde kullanılır.

$>$ Nitel Örnekedinme: Sayısal çıktılardan çok, süreç veya uygulamaların karşılaştırılmasının ön planda olduğu yöntemde, Bilgi Yönetimi Değerleme Aracı (Knowledge Management Assessment Tool-KMAT) adı verilen bir araç kullanılmaktadır. KMAT; liderlik, teknoloji, örgüt kültürü ve süreçlerle ilgili üst düzey bir incelemede bulunarak örgütlere, bilgiyi daha iyi nasıl yönetecekleri hakkında yardım etmeyi amaçlamaktadır.

Özetle bu beş yaklaşım; BBM yöneticilerinin dikkatlerini rakiplere ya da alanında en iyi olan örgütlere yöneltmesini ve kendi örgütlerini 
daha güçlü kılmak için diğer kurum/kuruluşlara ait ve açık erişimi mümkün olan bilgilerden yararlanmasını sağlamaktadır.

\section{Örnekedinme Süreci}

Örnekedinme süreci, bir BBM'nin zayıf yönlerini belirlemek ve kabul etmekten başlamaktadır. Daha sonra bu işi diğer örgütlerin nasıl yaptığını öğrenmek, onu kendi bünyesine uyarlamak ve en iyiyi yakalamak biçiminde gelişim göstermektedir. Örnekedinme sürecinde temel aşamalar farklı kaynaklarda, kıyaslanan faaliyete ya da alana bağlı olarak 4-6 aşama çerçevesinde verilmektedir. Bu çalışmada beş aşamalı bir süreçten söz edilecektir (Ohinata, 1994, ss. 50-53) (Bkz. Şekil 1).

Birinci Adım - Örgüt-içi Çalışma: Bu aşamada BBM, hangi alan(lar)da örnekedinme yapacağını belirler. Aşağıdaki sorulara verilecek yanıtlar, söz konusu alan(lar)ın belirlenmesinde kullanılabilir:

> BBM'nin başarısını etkileyen önemli faktörler nelerdir? Örneğin; kullanıcı memnuniyeti, yeni teknoloji olanakları, BBM'de açılması düşünülen yeni hizmet alanları vb.

$>\quad$ Hangi bölümler fazla sorun yaratmaktadır? Örneğin; satın alma, ödünç verme, danışma kaynakları (Robbins ve Daniels, 2001), kataloglama-sınıflama, süreli yayınlar vb.

$>\quad$ Hangi bölümler müşteri memnuniyetine katkı sağlamakta, hangileri beklentileri karşılayamamaktadır?

BBM'yi rekabet açısından en fazla etkileyen ve baskı altına alan faktörler nelerdir? Örneğin; tedarikçi firmalar, düşük fiyatı elektronik ve/veya basılı yayınlar, döviz kurunda yaşanan değişme vb.

$>\quad$ Örgütü rekabet edebilme açısından farklı kılmak için hangi işlevler en fazla potansiyele sahiptir? Örneğin; veri tabanı hizmetleri, elektronik ödünç verme/kitap ayırtma hizmeti, güncel duyuru hizmeti, kütüphanelerarası ödünç verme ve fotokopi hizmeti vb. 


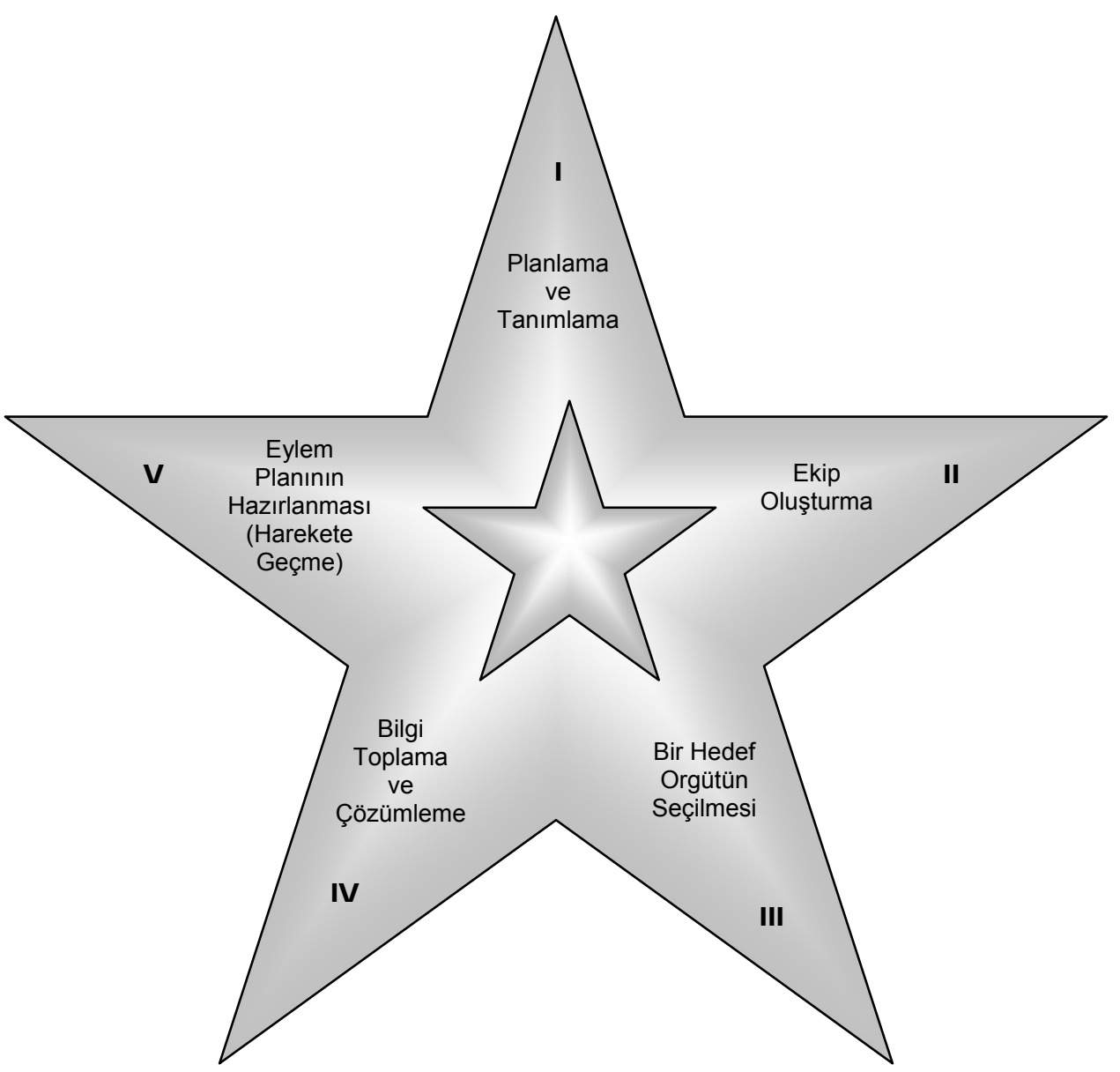

Şekil 1: Örnekedinme Süreci Aşamaları (Kaynak: Ohinata, 1994, s. 51)

Belirtilen sorulara ve benzerlerine verilecek yanıtlar, örgütün geçmiş verileri; konsorsiyum, mesleki dernekler, yayınlar ya da BBM İnternet sitelerinde yer alan bilgilerle karşılaştırılarak, örgüt için ön çalışmalar tamamlanır. Böylece, hem örnekedinmenin uygulanacağı alanlar belirlenmiş hem de örnekedinmenin kapsamı ortaya konmuş olur. 
Íkinci Adım - Ekip Oluşturma: Örnekedinme çalışmalarının başarısı, büyük ölçüde ekip çalışmasının etkinliğine bağlıdır. Örnekedinme ekibi, genel olarak proje lideri ile veri toplama ve çözümlenmesinden sorumlu 2-5 kişiden oluşur. Projeye dâhil edilen kişiler, ilgili sürecin sahipleri ya da ilgili süreçte çalışan bireyler olmalıdır. Bu aşamada üst yönetimin örnekedinme ekibine yetki desteği sağlaması ve örnekedinme çalışmalarına rehber olmak üzere bir amaçlar tablosu oluşturması gerekmektedir.

Üçüncü Adım - Bir Hedef Örgütün Seçilmesi: Uygulama için hedef örgüt türlerinin ve yerlerinin belirlenmesi öncelik taşımaktadır. Çünkü örnekedinme açısından ortaklar; bilgi alışverişinde bulunulacak örgütler anlamındadır. BBM'lerin örnekedinme yapabilecekleri, sınıfında en iyi olan örgütler şu dört biçimde seçilebilir:

Doğrudan Rakipler: Bilgi sektöründe benzer hizmetleri üreten örgütlerdir. Örneğin; bir üniversite kütüphanesi, diğer üniversite kütüphaneleriyle kendisini kıyaslayabilir.

> Dolaylı Rakipler: Bu tür rakipler, bilgi sektöründe faaliyet gösterdiği halde birbirleriyle doğrudan rekabet etmeyen BBM'lerdir. Örneğin; Milli Kütüphane, üniversite kütüphanesinin dolaylı rakibi konumundadır.

$>$ Görünmeyen Rakipler: Henüz rekabet etme gücüne kavuşmamış, fakat gelecekte rakip olabileceği muhtemel olan örgütlerdir. Buna en güzel örnek; Amazon.com ve Google'ın oluşturduğu Amazoogle yaklaşımıdır. "Bu yaklaşım, bilgi kaynaklarıyla ilgili olarak hem bibliyografik bilgilere hem de ilgili kaynakların tam metinlerine ağ aracılığıyla erişim sağlanmasını gerektirmektedir. Günümüzde 100 'den fazla kütüphane, dermelerini ve veri tabanlarını Google Scholar'ın (scholar.google.com) örümceklerine açarak bibliyografik ve tam metin bilgi kaynaklarının dizinlenmesini sağlamış ve bu kaynakları daha büyük kullanıcı gruplarının kullanımına sunmuşlardır" (Tonta, 2006). Bundan dolayı Google ve Amazon.com gibi oluşumlarla işbirliğine gitmeyen BBM'ler onların rakibi konumundadır.

> Sektör Dışından Örgütler: Aynı sektörde faaliyet göstermeyen örgütlerin birbirlerine kıyasla yaptıkları örnekedinme, en yaratıcı örnekedinme biçimidir. Örneğin; yönetim konusunda BBM'ler, ticari işletmeleri örnek alarak, çağdaş yönetim tekniklerini kendi 
yapılarına uygulayabilmektedirler. Süreçlerini, sadece bilgi sektörü içindeki rakiplerin ne yaptıklarını izleyerek iyileştirmeye çalışan bir BBM; sürekli olarak yalnızca bir yakalama durumunu sürdürmektedir. Oysa bilgi sektörü dışından işletmelerle kıyaslama yapılarak yeni bir teknik ya da süreç geliştirilebilir ve rakibi yakalama durumundan rakibi geçebilme durumuna ulaşılabilir.

BBM'ler işlevlerini iyileştirmek için uygulamalarını en başarıı uygulamalarla kıyaslamak durumundadır. Bunun için, en iyi uygulamaların araştırılması ve örnekedinme kaynaklarının belirlenmesi gerekmektedir. Örneğin; BBM'lerin ağ ortamında vazgeçilmez sanal kütüphaneler olabilmeleri için kaynak ve hizmetlerin hızla ağa taşınması, bunun için de gereken yeniden yapılanma çalışmalarının başlatılması gerekmektedir.

Dördüncü Adım - Bilgi Toplama ve Çözümleme: Örnekedinme ortağı belirlendikten sonra bilginin nasıl toplanacağına karar vermek gerekir. Bilgi kaynağı olarak; çalışanlardan, yöneticilerden, yıllık raporlardan, mesleki kuruluşlardan ve yayınlardan yararlanılabilir. Örnekedinme uygulamalarında genel olarak üç tür bilgiden yararlanılır. Bunlar aynı zamanda örnekedinme türlerinin sınıflandırılmasında da kullanılan ölçütlerdir (Maviş, 1998, ss. 230-231):

Ürün/Hizmet Yönlü Örnekedinme: Örnekedinen örgütün, ürünlerin/hizmetlerini geliştirmesi için; seçilen ortağın (kıyaslanacak örgütün) ürünlerin/hizmetlerine ilişkin bilgileri toplama sürecidir.

İşlev/Süreç Yönlü Örnekedinme: Örnekedinen örgütün süreçlerini iyileştirmesi için, seçilen ortağın süreçlerine ilişkin bilgileri toplaması faaliyetidir. Örneğin; satın alma işlemleri vb.

Stratejik Örnekedinme: Kıyaslanacak örgüt stratejilerine ve/veya stratejik kararlara ilişkin bilgilerin toplanması sürecidir. Örneğin; BBM'nin ödünç verme politikası, koleksiyon geliştirme politikası, kullanıcı grubunun belirlenmesi vb.

Örnekedinme projesinde kullanılmak üzere bilginin toplanması ve paylaşılmasından sonra örnekedinme aracını kullanan BBM bir durum çözümlemesi yaparak, kendi başarımı ile kıyaslanacak örgütün başarımı arasındaki farkı belirler. Bu farklıkaşma fazlalık literatürde "açıklık" olarak ifade edilmektedir. Bu açıklık, BBM'nin geliştirmek istediği ve örnekedinme projesi olarak belirlenen 
hizmet, işlev ve strateji açısından değerlerle ifade edilir (Maviş, 1998, s. 231).

Beşinci Adım - Eylem Planının Hazırlanması ve Harekete Geçme: Uygulama aşamasına gelindiğinde hedeflerin bütün BBM çalışanları tarafından içselleştirilmesi sağlanır, gerekli kaynaklar ayrılır, uygulayıcılara gerekli eğitimler verilir, örgütsel planlar hazırlanır ve en önemlisi üst yönetimin desteği sağlanır (Bedük, 2002, s. 46). BBM, tüm aşamaları geçtikten sonra örnekedinme projesini tamamlamak üzere harekete geçmek durumundadır. Bundan dolayı BBM'lerin, süreçlerini iyileştirmek amacıyla, kıyaslanan örgüt ile arasındaki farkı kapatacak bir dizi kararları alarak, kaçınılmaz değişimi gerçekleştirmesi gerekmektedir (Maviş, 1998, s. 232).

\section{Dünyadaki Örnekedinme Uygulamalarından Örnekler}

ABD'de örnekedinme uygulamalarının gelişmesiyle birlikte konuya ilişkin bir takım yeni düzenlemeler oluşturulmuştur. Sözgelimi; örnekedinmenin temel koşulu kıyaslanan işletmenin olaydan haberdar olması, örnekedinme işlemlerinde taraflararası ilişkilerin "Örnekedinme Takas Odaları" tarafından düzenlenmesi koşulu aranır. Aynı biçimde örnekedinmede kullanılacak veri tabanları oluşturulurken bu veri tabanlarını üretenler bunların kıyaslamada kullanılabileceğini önceden bilirler.

Japonya'da ise; örnekedinme işlemlerinde (Japon kültürünün bir uzantısı olarak) işletmeler, iyi oldukları konuları, öğrenilenleri ya da yeni gelişen fikirlerini birbirleriyle açıkıkla ve gönüllü olarak paylaşmaktadırlar (Maviş, 1998, s. 222-223).

BBM'lerde kalite kavramı, 1969 yılında ilk kez Lancaster tarafından ele alınarak, Index Medicus veri tabanındaki taramaların başarısı ve kalitesi incelenmiştir (Whitehall 1994, s. 100). TKY felsefesi; İngiltere, Avustralya ve ABD'deki BBM'lerde yaygın olarak uygulanmaktadır. ABD'de 1994 sonu itibarıyla 415 okul, kolej ve üniversite kütüphanesinde TKY'nın uygulanmakta olduğu belirtilmektedir. İngiltere ve Avustralya'da da, bu düzeyde olmasa bile, çalışmalar sürdürülmektedir (Yılmaz, 2003, ss. 262-263).

Webb (1995) yaptığı bir çalışmada, TKY ve örnekedinme tekniklerinin özel kütüphanelerde uygulanabilirliğini araştırmıştır. Yazar çalışmasında TKY ve örnekedinme gibi yönetsel araçların özel kütüphane işlevlerinin etkinliğini artırdığını belirlemiştir. 
İngiltere'deki halk kütüphanelerinde yıllardır performans ölçümü çalışmaları yapılmaktadır. Halk kütüphanelerinin hangi süreçleri, niçin ve nasıl ölçmeleri gerektiği konusunda pek çok yayın bulunmaktadır. King Research Ltd. (1990); Sumsion (1993), Sumsion (1999), Chartered Institute of Public Finance and Accountancy-CIPFA (1999); Department for Culture, Media and Sport-DCMS (1997) ve Favret (2000) bunlardan başlıcalarıdır.

Diğer taraftan DCMS, halk kütüphanelerinin yıllık planlarında, en yüksek katma değere ulaşılabilmesi için onlara çeşitli standartlar sağlayan bir hizmet sunmaktadır. Bu hizmet standartları, kütüphane hizmetlerinin izlenmesinde ve değerlendirilmesinde bir mihenk taşı (benchmark) olabilecek niteliktedir (Favret, 2000, s. 345).

Çok geniş bir İngiliz halk kütüphane topluluğu tarafından yararlanılabilecek istatistiklerin kullanılabilirliğini inceleyen çalışmada (Creaser, 2001), bir örnekedinme yöntem yaklaşımı tanımlanmakta ve kütüphane yönetimine sağlanabilecek en iyi uygulamaların genişletilmiş örnekleri bulunmaktadır. Bu bağlamda; tam zamanlı çalışan uzman ve destek personel, kitap ve görsel-işitsel yayınlardan oluşan kütüphane dermesi, yeni gelen kitaplar ve görsel-işitsel kaynaklar ve kütüphane kullanım alanı "girdiler" biçiminde sistemleştirilmiştir. "Çıktı" birimlerini ise; başlık bazında kitap ve görsel-işitsel kaynaklar, kullanıcı istekleri, taramalar, ziyaretler ve memnuniyet oranı gibi istatistiksel başarım ölçümleri oluşturulmaktadır. Geliştirilmiş olan ilgili yöntem yaklaşımı diğer halk kütüphanesi hizmetlerinde uygulanabilecek niteliktedir.

Robbins ve Daniels (2001), akademik tıp kütüphanelerindeki danışma hizmetlerinin etkinliğinin artırılmasına yönelik olarak yapılan bir ön örnekedinme araştırmasını incelemişlerdir. Çalışmada yazarlar, çeşitli kaynaklardan derledikleri kullanıcı memnuniyetini ölçmeye dönük (somut kaynaklar, güvenirlilik, yanıt verme, teminat ve empati boyutlarındaki) anket soruları hazırlayarak, beş akademik tıp kütüphanesinde uygulamışlardır. Sonuçta kıyaslama yapılabilecek en iyi kütüphanelerin belirlendiği araştırmanın bulguları, ileride örnekedinme çabası içine girecek BBM'lere rehber niteliğindedir.

Ruthven ve Magnay'in (2002) çalışmasında, Araştırma Kütüphaneleri Derneği'nin yürüttüğü "Kütüphanelerarası Ödünç Verme İşlemlerinin Performans Ölçümü” konulu bir araştırmanın örnekedinme bulgularına yer verilmektedir. Araştırmada, kütüphanelerarası ödünç verme işlemlerinin yüksek başarım özellikleri tanımlanarak; örnekedinme işlemlerinde kütüphanelere standart veri yardımı sağlanması 
amaçlanmaktadır. Çalışma sonunda, en iyi uygulamaların pekiştirilmesini hedef alan eğitim, kütüphane politikaları hakkında tartışma seminerleri, en iyi uygulamaların belirlenmesi ve geliştirilmesi ile uygulama işlemlerinin gerçekleştirilmesine dönük teşvik edilme konularına yer verilmektedir.

Laeven ve Smit (2003), Hollanda'daki üniversite kütüphanelerinde örnekedinme çalışmalarını incelemişlerdir. Çalışma, örnekedinme sürecinde performans araçlarını belirleyerek, kütüphane işlevlerini verimli kılmayı amaçlamaktadır. Yazarlar, örnekedinmenin toplam kaliteye ulaşmada etkin bir araç olmasına rağmen, Hollanda kütüphanelerinin örnekedinme sisteminden istenilen düzeyde yararlanmadıkları ve çalışma sonunda elde edilen bulguların da mükemmellikten uzak olduğu saptamasında bulunmuşlardır.

Pors, Dixon ve Robson (2004) tarafından yazılan bir makalede ise, kütüphanelerde kalite ölçüm araçlarının benimsenmesi ve kullanımı üzerinde etkili olan faktörler, Danimarka ve İngiltere'deki farklı uygulamalarla karşılaştırılmaktadır. Yazarlar, içinde örnekedinmenin de yer aldığı yönetim bilgi sistemleri, stratejik planlama, kullanıcı anketleri, işgören anketleri, bilgi yönetimi, amaçlara göre yönetim, kalite sistemleri, proje yönetimi gibi 21 araç ve yaklaşımı, iki ülke kütüphanelerini kıyaslayarak test etmektedir. Araştırma sonuçları, örnekedinme uygulamalarının Danimarka'ya oranla İngiltere'de daha yaygın kullanıldığını göstermektedir. Buna karşın Danimarka'daki pek çok kütüphanenin, örnekedinme yerine kıyaslayarak öğrenme (benchlearning) yolunu tercih ettiği belirtilmektedir.

Rowley'in (2005) yaptığı bir çalışmada kalite, örnekedinme ve performans yönetimi konusunda İngiliz BBM'lerindeki güncel uygulamalar incelenmektedir. Çalışmada, bütün kamu kütüphanelerinin kalite yönetim süreçlerinde, örnekedinmede ve performans ölçümünde sürekli olarak gelişme intiyacı içerisinde bulundukları saptanmıştır.

Tyler (2005) makalesinde, Avustralya'daki içinde kütüphanelerin de yer aldığı kâr amacı gütmeyen bir sektörde, örnekedinme uygulamalarını incelemektedir. Araştırma kapsamında 50'den daha fazla çalışanı olan 15 örgüt bulunmaktadır. Çalışma sonucunda örnekedinmenin; sağlık, eğitim ve sivil toplum örgütlerindeki örgütsel performansın geliştirilmesinde yaşamsal bir öneme sahip olduğu vurgulanmaktadır.

Yeates ve Guy'ın (2006) yaptığı bir çalışmada ise, İngiltere'deki halk kütüphaneleri, müze ve arşiv dermesinin Web ortamına aktarımı konusundaki çalışmaların örnekedinme aracıyla geliştirilmesi 
incelenmektedir. Çalışma sonunda; kültürel mirasın sayısallaştırılması ve Web üzerinden yayımlanması konusunda deneyim eksiği olan halk kütüphaneleri, müze ve arşivlerde çalışan personelin eğitilip, bir konsorsiyum çatısı altında bilgi ve deneyim paylaşımına sokulmasının gereği vurgulanmaktadır.

\section{Türkiye'deki Örnekler}

Ülkemizdeki bilgi sektörüne bakıldığında, TKY ve onun bir aracı olan örnekedinmenin BBM'lerin çok azında uygulandığı görülmektedir. Anılan yönetim tekniklerinin ülkemiz BBM'lerinde uygulanmama nedenleri aşağıdaki biçimde özetlenebilir (Yılmaz, 2003, s. 265):

Anılan kurumlarda TKY bilincinin henüz oluşmaması,

$>$ Yetişmiş ve bilinçli personelin az sayıda olması,

$>\quad$ Üst yönetimin bu konudaki bilgi ve destek eksikliği,

$>$ Bütçe olanaklarının sınırlı olması,

$>\quad$ "TKY olmasa da olur" şeklindeki eski anlayışın izleri,

$>$ Geleneksel yapıyı koruma düşüncesi,

$>$ Teknolojik olanakların yetersizliği,

$>\quad$ Bilgi talebi konusunda kullanıcının bilinçsizliği,

> BBM örgütlerinde bürokratik ve basamaksal yapının var oluşu.

Türkiye'deki lisansüstü tez çalışmaları ele alındığında, BBM'lerde TKY, kullanıcı merkezli yapılanma, kullanıcı memnuniyeti, örnekedinme vb. konularda, yakın zamanda hazırlanmış bir yüksek lisans tezi (Çukadar, 1999) dışında başka bir çalışmanın bulunmadığı; buna karşılık, BBM'lerde kullanıcı eğitimi, personel yönetimi, yönetim, organizasyon ve iş tatmini gibi konularda çeşitli çalışmaların yapıldığı görülmektedir (Yılmaz, 2005, s. 191). Erol Yılmaz'ın 2005 yılında yayımladığı "Bilgi Merkezlerinde Toplam Kalite Yönetimi" başlıklı kitabı, TKY'nin üniversite kütüphanelerinde uygulanması konusunda somut katkıları olan önemli bir çalışmadır. TKY konusunda ülkemizde yapılmış çeşitli makale, bildiri vb. türde çalışmalar da bulunmaktadır (Ayrıntı için bkz. Yılmaz, 2005, ss. 199-211).

Ülkemiz BBM'lerindeki TKY uygulamalarına bakıldığı zaman, literatüre geçmiş olan, iki vakıf üniversite kütüphanesinde ve henüz literatüre yansımayan bir kamu üniversite kütüphanesinde çalışmaların yürütülmekte olduğu görülmektedir.

TKY'nin uygulandığı BBM'lerden birisi Başkent Üniversitesi Kütüphanesi'dir. 1998 yılı Mayıs ayında üniversite genelinde TS-EN-ISO 
9001 Kalite Sistem Belgesi'nin alınmasıyla, Başkent Üniversitesi'nin tüm birimlerinde olduğu gibi, kütüphanede de TKY çalışmaları başlamıştır (Arda, 2000, s. 192).

TKY konusunda bir diğer model geliştirme çalışması ise İstanbul Bilgi Üniversitesi'nde (IBÜ) gerçekleştirilmiştir. İBÜ Kütüphanesi'nde bu konuda aslında birçok işin yapıldığı, fakat bunlarda belirli bir düzeninin olmadığı sonucuna varılmıştır. TKY modeli çalışmasında, yapılanları belirli bir düzene koymak ve belirli bir plana göre sürekli olarak iyileştirme hedeflenmiştir. Kurumun en önemli varlığının müşterileri/kullanıcıları olduğu vurgulanmıştır. TKY bilgisi ışığında yapılan değerlendirmelere göre, İBÜ Kütüphanesi açısından kullanıcı ve sağlama hizmetlerinde olumlu yönde değişiklikler olduğu görülmüştür. Örneğin, kütüphane kullanıcılarına yönelik olarak düzenlenen "Kütüphane Kullanım Seminerleri”nin devamlılığının sağlanmasının yanında, bu seminerlerin Sinema-Televizyon Bölümü ile işbirliği halinde videokaset kaydının yapılmasının ve kütüphanede bulunan videokaset dermesine dâhil edilmesinin kullanıcı eğitimi açısından faydalı olacağı düşünülerek konu yönetime sunulmuş ve olumlu yanıt alınmıştır (Çukadar, 1999, s. 97).

Ülkemizde TKY konusunda yapılan bir diğer uygulama, Orta Doğu Teknik Üniversitesi (ODTÜ) Kütüphanesi tarafından yürütülmektedir. 2003 yılının Temmuz ayından itibaren KalDer (Kalite Derneği) ile birlikte Kütüphane'deki verimliliğin artırılması ve maliyetlerin düşürülmesini hedefleyen toplam kalite çalışmalarına başlanmıştır. KalDer'in 2003 yılında düzenlediği "Süreç Yönetimi ve İyileştirilmesi" ve "ISO 9000: 2000 Kalite Yönetim Sistemi” başlıklı seminerlere katılım sağlanmıştır. Alınan eğitimden sonra kütüphanenin örgüt şeması oluşturulmuş ve temel süreçler belirlenmiştir.

$\mathrm{Bu}$ çerçevede yapılan iyileştirmelerin bazıları aşağıda özetlenmektedir (Karasözen ve Gürbüz, 2004):

Iç düzenleme açısından;

$>$ Personelin görev tanımları yapılarak; bilgi ve deneyimlerine göre personel, uygun birimlerde görevlendirilmiştir.

$>$ Personelin aylık performans değerlendirmeleri uluslararası standartlara uygun olarak yapılmaktadır.

$>\quad$ Birimler arasında yeniden yapılandırmaya gidilmiş, Yayın Sağlama ve Kataloglama bölümleri birleştirilerek tek bir birim haline getirilmiştir. 
> Kütüphanede elle yapılan sipariş, kitapların teknik işlemleri, fatura işleme, duyuru, kataloglama-sınıflama gibi işlerde bilgi teknolojisinden (BT) yararlanılmaya başlanmıştır.

> Danışma, süreli yayınlar bölümleri ve kütüphane web sitesi yeniden düzenlenmiştir.

Dermenin geliştirilmesi ve yönetimi açısından;

- Kitap ve basılı-elektronik süreli yayın dermesi durumunun belirlenerek diğer üniversite kütüphaneleriyle kıyaslanabilir bir çekirdek dermenin oluşturulması çalışmalarına başlanmıştır.

$>$ Tam metin veren çevrim-içi veri tabanlarına abonelik sayısı artırılmıştır.

Hizmet-içi eğitim ve değişim programları açısından;

Kütüphane çalışanlarına bilgisayar programlarının kullanımı, yönetim-organizasyon, dosyalama, raporlama ve istatistik toplama eğitimleri verilmektedir.

$>\quad$ Bilkent Üniversitesi Kütüphanesi ve ODTÜ Kütüphanesi arasında bir ay süreyle bir değişim programı uygulanarak; personele, farklı uygulamaları görme, değerlendirme ve kıyaslama olanağı sağlanmıştır.

Fiziksel yapı ve bilgisayar donanımı açısından;

$>$ Ayrık kitaplar (reserve) ve danışma bölümlerindeki sandalye ve masalar yenilenmiştir.

> Raflardaki yığılmaların hafifletilebilmesi için "depo kütüphanesi" oluşturulması çalışmaları başlatılmıştır.

$>\quad$ Internet bağlantılı bilgisayarların kapasitesi yükseltilerek gerekli olan ek donanım (CD, kulaklık, yazıcı vb.) sağlanmıştır.

ODTÜ Kütüphanesi'nde, performansa dayalı bütçeleme çalışmaları kapsamında, her üç ve altı aylık dönemlerde raporlama işlemleri yürütülmektedir. Bu raporlarda, stratejik plan doğrultusunda ulaşılan hedefler ve kullanıcı memnuniyetine yönelik hizmetler yer almaktadır. Kütüphanenin yıllık bütçesi, kullanıcı talepleri ve memnuniyetleri, 
dünyadaki kütüphanecilik alanındaki teknolojik gelişmeler, basılı ve elektronik dermenin kullanımı göz önünde bulundurularak düzenlenmektedir.

\section{Sonuç ve Öneriler}

Günümüzde BBM yöneticilerinin yönettikleri örgütün bilgi sektöründeki mevcut durumunun ne olduğunu ve gelecekte nerelerde olacağını değerlendirebilmeleri için, strateji oluşturma ve uygulama düzeylerinde birçok başarım ölçütlerinin belirlenip, zaman içindeki gelişmelerin bu kriterlere göre ölçülmesi gerekmektedir. Son zamanların en ünlü başarım ölçütleri arasında, kullanıcı ve işgörene sunulan ürün/hizmet geliştirme hızı, soruların yanıtlanma hızı ve güvenirlik, sürekli iyileştirmeye eğilim ve istek, örnek olarak verilebilir. Ancak bu başarım ölçütleri ve ölçümlerinin de dış çevre koşullarında yaşanan değişimlere ayak uydurmayı tam olarak sağladığı söylenemez. Bundan dolayı BBM'lerde daha dinamik bir sistem arayışı söz konusu olacaktır. İşte bu arayışlar, "örnekedinme" uygulamalarını daha da vazgeçilmez kılmaktadır.

Örnekedinme, son yıllarda sürekli gelişime inanmış BBM'lerin, müşteri memnuniyetini ve rekabet üstünlüğünü hedefleyerek; ürün, hizmet ve süreçlerde mükemmellik örneği olan lider örgütlerin gelişmiş ve etkin uygulamalarını kendi bünyelerine uyarlamak amacıyla kullanacakları başarılı ve sistemli bir karşılaştırmalı ölçme yöntemi olarak kabul görmektedir.

Ülkemizdeki mesleki literatüre ve uygulama örneklerine bakıldığı zaman önemli bir TKY aracı olan örnekedinmenin; bilim insanı tarafından yeterince incelenmediği ve buna koşut olarak da BBM'lerin çok azında uygulama isteği görülmektedir. Türkiye'de örnekedinme çalışması yapan örgütlerin yeterli bilgi düzeyine sahip olmadıkları, örnekedinme ortağı olmanın yararına inanılmadığı, örgütlerde TKY anlayışının tam olarak benimsenmediği, üst yönetim desteğinin eksikliği, BBM yönetimi ve çalışanlarının bilgi eksikliği ve bilim insanlarının bu konuya gereken önemi vermemeleri bunun belli başlı nedenleridir. $\mathrm{Bu}$ bağlamda örnekedinmenin ülkemiz BBM'lerinde daha yaygın ve etkin kullanımını sağlamak için ulusal ve örgütsel düzeyde alınması gereken önlemlere ilişkin öneriler aşağıda belirtilmiştir: 


\section{Ulusal Düzeyde Alınması Gereken Önlemler}

KalDer'in (Kalite Derneği) Türkiye'deki tüm özel/kamu kurum ve kuruluşları ile sivil toplum örgütlerine dünya çapında kalite seviyesine ulaşmaları ve rekabet güçlerini artırmaları için uygun ortamlar yaratmak amacıyla düzenlediği "Ulusal Kalite Kongreleri"nin sayı ve kapsamı artırılabilir.

$>\quad$ Türk Kütüphaneciler Derneği (TKD) ve Üniversite ve Araştırma Kütüphanecileri Derneği (ÜNAK) gibi mesleki örgütlerin düzenlemekte oldukları bilimsel kongre, sempozyum vb. etkinliklerde BBM'lerdeki TKY ve örnekedinme kuram ve uygulamalarına daha fazla yer verilebilir. Anılan dernekler, KalDer ve Millî Prodüktivite Merkezi'yle (MPM) eşgüdümlü olarak çalışabilirler.

$>$ TKY, örnekedinme, öğrenen organizasyonlar, süreçlerin yeniden değerlendirilmesi/değişim mühendisliği (re-engineering), performans değerlendirilmesi ve ölçümü gibi çağdaş yönetim teknik ve yaklaşımları konularında konsorsiyum(lar) / birlik(ler) oluşturulabilir ve bu konuda BBM'lere danışmanlık hizmeti sunulabilir.

$>$ Ülkemizdeki "Bilgi ve Belge Yönetimi" bölümlerinin ders içeriklerinde ve bilim insanının bilimsel çalışmalarında TKY, örnekedinme gibi çağdaş yaklaşım ve tekniklere daha fazla yer verilebilir.

\section{Örgütsel Düzeyde Alınması Gereken Önlemler}

"Siz çalışanlarınıza nasıl davranırsanız, onlar da müşterilerinize / kullanıcılarınıza öyle davranır" Çin atasözünden hareketle BBM yöneticileri, otokratik yönetim yaklaşım tarzını terk ederek; örgütsel kararlarda çalışanların da görüşlerine yer vermelidirler.

> BBM'nin yönetici ve işgörenlerinin çağdaş yönetim yaklaşımları ve bilgi teknolojileri boyutlarındaki eğitim programlarına tabi tutulmalarıyla gereksiz kaynak kullanımı ve örgütsel çatışmalar en aza indirilebilir. Bu nedenle, BBM'ler ve varsa bunlara bağlı şube birimleri personelinin hizmet-içi eğitim programlarına katılmaları önerilebilir.

BBM'lerde çalışan yönetici ve bilgi-belge yönetimi uzmanlarının yönetim-organizasyon ve halkla ilişkiler gibi diğer disiplinlerde lisansüstü düzeyde çalışmalar yapmaları özendirilebilir. 
$>$ BBM yöneticileri, örgütsel etkinliği artırmak için; dış müşteri (kullanıcı) ve iç müşteri (işgören) odaklı yönetim tarzını benimsemelidirler.

> BBM'ler sektör içinden ve/veya dışından en iyi uygulamaları bularak, kendi süreçleriyle kıyaslama yoluna gitmelidirler.

> TKY ve örnekedinme uygulamalarında üst yönetimin mutlak desteği ve katıımı sağlanmalıdır.

$>\quad$ Etkin ve sürekli değişim odaklı olunmalıdır.

$>\quad$ BBM'lerin kendi süreçlerinde ne ölçüde yeterli olduğunu belirlemesi ve aynı zamanda zayıf yönlerini de tanımlayarak fırsat ve tehdit unsurlarını çözümlemesi gerekmektedir (FÜTZ Analizi: Fırsatlar, Üstünlükler, Tehditler, Zayıf Yönler - SWOT Analysis: Strenghts, Weaknesses, Opportunities, Threats).

$>\quad$ BBM'lerin değişim ve uyum sağlamaya istekli olması gerekir.

$>$ Örnekedinmeye kararlı başlamak ve ilgili süreci disiplinli bir biçimde sürdürmek gerekir.

> Hizmet ölçümlemesine ve sonuçlara odaklanmamak, aksine süreçlere odaklanmak gerekir.

> Bilindiği gibi çağdaş yönetim anlayışı, Türkiye'ye yabancı kökenli kaynaklardan gelmektedir. İthal edilen bu bilgiyi daha etkin bir biçimde anlayabilmek ve uygulayabilmek için, BBM çalışanlarının yabancı dil düzeyleri geliştirilebilir.

\section{Kaynakça}

Arda, S. (2000). Başkent Üniversitesi kütüphanesinin kuruluşu, TS-EN-ISO 9000 kalite çalışmaları ve gelişmesi. Bilgi Dünyası, 1(1): 192-195.

Bedük, A. (2002). Benchmarking. Ankara: Nobel Yayın Dağıtım Ltd. Şti.

Capital Guide 38. (1997). İş dünyasının yeni gözdesi: Benchmarking. (Ekim).

Chartered Institute of Public Finance and Accountancy. (1999). Public library statistics 1998-99 actuals. London: CIPFA.

Creaser, C. (2001). Comparing performance of service points in public libraries. Performance Measurement and Metrics, 2(2): 109-135.

Çukadar, S. (1999). Toplam Kalite Yönetiminin kütüphanelerde uygulanması: İstanbul Bilgi Üniversitesi Kütüphanesi için Toplam Kalite Yönetimi sisteminin geliştirilmesi. Yayımlanmamış yüksek lisans tezi, İstanbul Üniversitesi, İstanbul.

Department for Culture, Media and Sport. (1997). Annual library plans guidelines. Guidance note. London: DCMS. 
Favret, L. (2000). Benchmarking, annual library plans and best value: The implications for public libraries. Library Management, 21(7): 340-348.

Jager, M. (1999). The KMAT: Benchmarking knowledge management. Library Management, 20(7): 36-37.

Karasözen, B. ve Gürbüz, E. (2004). ODTÜ Kütüphanesi Performans Bütçeleme Projesi ve Toplam Kalite çalışmaları. 5. Kamu Kalite Sempozyumu 9-10 Haziran 2004, Ankara. Ankara: ODTÜ. 14 Haziran 2006 tarihinde ftp://ftp.lib.metu.edu.tr/doc/kalder.pdf adresinden erişildi.

King Research Ltd. (1990). Keys to success: Performance indicators for public libraries. London: HMSO.

Kurulgan, M. (2004). Bilgi teknolojisinin üniversite kütüphanelerinde yönetim işlevleri üzerine etkileri ve Türkiye'deki uygulamaya ilişkin bir araştırma. Yayımlanmamış doktora tezi, Anadolu Üniversitesi, Eskişehir.

Laeven, H. ve Smit, A. (2003). A project to benchmark university libraries in the Netherlands. Library Management, 24(6/7): 291-304.

Maviş, F. (1998). Otel işletmelerinde örnek edinme. Anadolu Üniversitesi IiBF Dergisi, 14 (1-2): 217-234.

Ohinata, Y. (1994). Benchmarking: The Japanese experience. Long Range Planning, 27(4): 48-53.

Pors, N.O., Dixon, P. ve Robson, H. (2004). The employment of quality measures in libraries: Cultural differences, institutional imperatives and managerial profiles. Performance Measurement and Metrics, 5(1): 20-27.

Robbins, K ve Daniels, K. (2001). Benchmarking reference desk service in academic health science libraries: A preliminary survey. College \& Research Libraries. 8 Haziran 2006 tarihinde http://www.ala.org/ala/ acrl/acrlpubs/crljournal/backissues2001b/july01/robbins.pdf adresinden erişildi.

Rowley, J. (2005). Making sense of the quality maze: Perspectives for public and academic libraries, Library Management, 26 (8/9): 508-518.

Ruthven, T. ve Magnay, S. (2002). Top performing interlending operations: Results of the Australian benchmarking study. Interlending \& Document Supply, 30(2): 73-79.

Sumsion, J. (1999). M. Line, G. Mackenzie ve P. Sturges (Eds.). Librarianship and Information Work Worldwide içinde (ss. 177-207). London: Bowker Saur.

Sumsion, J. (1993). Practical performance indicators-1992. Loughborough: Library and Information Statistisc Unit (LISU). 
Tonta, Y. (2006). Bilgi yönetiminde son gelişmeler: Amazoogle, işbirliği ve açık erişim. Akademik Bilişim '06'da sunulan bildiri. 8 Haziran 2006 tarihinde http://yunus.hacettepe.edu.tr/ tonta/yayinlar/tonta-ab-2006denizli-bilgi-yonetiminde-son-gelismeler.pdf adresinden erişildi.

Tyler, M.C. (2005). Benchmarking in the non-profit sector in Australia. Benchmarking: An International Journal, 12(3): 219-235.

Webb, S.P. (1995). Pursuing quality in special libraries. Library Review, 44(7): $5-7$.

Whitehall, T. (1994). Quality in library and information service: A review. R.M. O'Neil (Ed.). Total quality management in libraries: a sourcebook içinde (ss. 100-121). Englewood: Libraries Unlimited.

Yeates, R. ve Guy, D. (2006). Collaborative working for large digitisation projects. Program: Electronic Library and Information Systems, 40(2): 137-156.

Yılmaz, E. (2005). Bilgi merkezlerinde toplam kalite yönetimi. Ankara: Alp Yayınevi.

Yılmaz, M. (2003). Bilgi merkezleri ve Toplam Kalite Yönetimi ilişkisi: Bir uygulama. Doğuş Üniversitesi Dergisi, 4(2): 257-268. 